\title{
混合調製を含めた注射薬調剤に適した 注射オーダエントリシステムの構筑と評価
}

\author{
名徳倫明*，下村一徳，川口進一，土師久幸 \\ 市立池田病院薬剤部
}

\section{Evaluation of an Order Entry System Created for the Dispensing and Mixing of Injections}

\author{
Michiaki Myotoku*, Kazunori Shimomura, Syunichi Kawaguchi and Hisayuki Haji \\ Department of Pharmacy, Municipal Ikeda Hospital
}

$\left[\begin{array}{l}\text { Received August 25, } 2004 \\ \text { Accepted October 30, 2004 }\end{array}\right]$

\begin{abstract}
At Ikeda Municipal Hospital, we created an order entry system for the dispensing and mixing of injections in November 2003. We then compared the numbers of injections that pharmacists mixed and administered to patients, the rates for injections mixed by pharmacists, return rates for injections mixed by pharmacists and dispensing error rates between the four months before and after introducing the system. Compared to before the introduction of the system, the number of injections that pharmacists mixed and administered to patients increased by about $40 \%$, the rate for injections mixed by pharmacists increased by $2 \%$ and the return rate for injections decreased by approximately $1 \%$. The dispensing error rate decreased to $0.26 \%$, a marked drop from the $2.23 \%$ error rate before introducing the system. Based on these results, we felt that our order entry system for the dispensing and mixing of injections was very useful.
\end{abstract}

Key words — order entry system, ordering system, prescription, injection, error

\section{緒言}

市立池田病院 (以下，当院と略す)薬剤部では，平成 9 年10月より，薬剂師が注射薬を調剂する上で，患者個別 の注射薬処方情報がわかりやすく，また必要事項を詳細 に記載できる注射薬処方せんを考案し，運用を開始し た1)。また，平成 12 年 4 月には病棟薬局を開設し，すべ ての注射薬を対象とした混合調製を含めた注射薬調剤を 開始する 2 など，注射薬による医療過誤防止対策に積極 的に関与してきた。

注射薬での医療過誤の原因としては, 数多くの因子が 考えられるが，その中には，注射薬処方せんへの記載ミ スや鑑査をする上で非常に重要である投与開始時間，投 与時間, 投与経路, 投与速度といった指示内容の記載不 備といったことからのヒューマンエラーに起因するミス も多く見られる3．注射オーダエントリシステムは，こ うしたヒューマンエラーの回避を可能とするといわれて
いる ${ }^{4)}$. また, 当院においても, 注射薬処方せんの伝達 の遅れや不備により，適正な注射薬調剂を行うことがで きなくなったり, 処方指示の変更や中止に伴い, 不必要 な調剤による返却がたびたび発生している。これらの問 題に関しても，注射オーダエントリシステムを導入する ことにより, 病態が不安定な患者の処方分を除いて，回 避可能であることが予測される.

当院では，これらの問題の回避も目的のひとつとし て，注射オーダエントリシステムの導入を検討した。し かし，当院で導入が検討された注射オーダエントリシス テムは，処方鑑査に必須な情報である投与開始時間の入 力に非常に手間がかかり，医師に入力を徹底させること が困難であった.さらに，1施行分を 1 処方として処方 せんに印字されない等の問題があった。

そこで，当院での混合調製を含めた注射薬調剂に適し た独自のオーダエントリシステムを構築し，平成15年11 月より運用を開始した。今回は，注射オーダエントリシ ステム導入前後での注射薬処方せん発行の傾向と混合調 
製を含めた注射薬調剤に対しての注射オーダエントリシ ステムの導入の影響を評価したので報告する.

\section{方法}

\section{1. 当院での注射オーダエントリシステムの概要}

Fig. 1 に当院で使用している注射オーダエントリシス テムの入力画面を示した. 当院で構築した注射オーダエ ントリシステム (日立造船(株) は, 注射薬処方せんを鑑査 する上で，薬剤名，投与量とともに必須項目である投与 開始時間，投与時間および投与速度等の入力に重点を置 いたシステムである. 処方オーダは, 薬剤名, 投与量, 投与方法，投与経路を選択した後に，投与開始時間，投 与時間または終了時間および投与速度を入力しなければ 処方せんが発行できないシステムとした。 また，入力を 簡便にするため, Fig. 1 に示したような画面選択方式と し，同一処方指示が指示時間の違いにより 2 回以上あっ ても，各投与開始時間を画面から選択し人力することに よりオーダを可能とした，ただし，手術や処置等，投与 開始時間が不確定なものや指示時間の不明確なものに関 しては，「時刻指定なし」または「指定なし(医師の指示 通り)」を選択することも可能とした.

Fig. 2 に当院で考案し使用している注射薬処方せんと 処方内容に修正があった注射薬処方せんの例を示した。
注射薬処方せんの形式は，薬物療法全体を把握した処方 鑑査が行えるように，1処方は 1 日分ではなく 1 施行分 の指示とし，投与指示日を挟んで過去 3 日，未来 3 日の 指示内容を出力可能とした. また, 修正指示が出た場合, 新規 - 中止処方 $(\bigcirc か ゙$ 新規処方, $\times$ が中止処方) 等の指示 変更箇所を網掛けとし, 指示変更のない処方も同時に出 力し， 1 枚の処方せんですべての処方情報の記載が可能 な形式とした。また，抗悪性腫瘍薬や中心静脈栄養輸液 処方は従来のように別処方せんとするのではなく，他の 注射薬との併用処方の内容がわかるように，同一処方せ ん内に記載することとした。

\section{2. 注射オーダエントリシステム導入後における評価}

1 ) 注射薬の処方本数および混合調製本数の比較

注射オーダエントリシステム導入前の 4 カ月間(平成 13 年 1 月 4 日〜 4 月 27 日) と導入後の 4 力月間(平成16年 1月 4 日〜 4 月30日)で，薬剤部が前日17時までに受け 付けた注射薬処方せんのうち, 点滴用に処方された 1 施 行分の注射薬 (以下, 点滴用注射薬と略す)の本数を集計 した。また，薬剤部で混合調製した点滴用注射薬の使用 本数および混合調製率を集計した。ささらに，混合調製本 数を投与開始時間10時から12時30分，12時30分から 15 時，15時から17時30分，17時30分から22時までの 4 つの 時間帯に分け，それぞれの時間帯の混合調製件数を集計

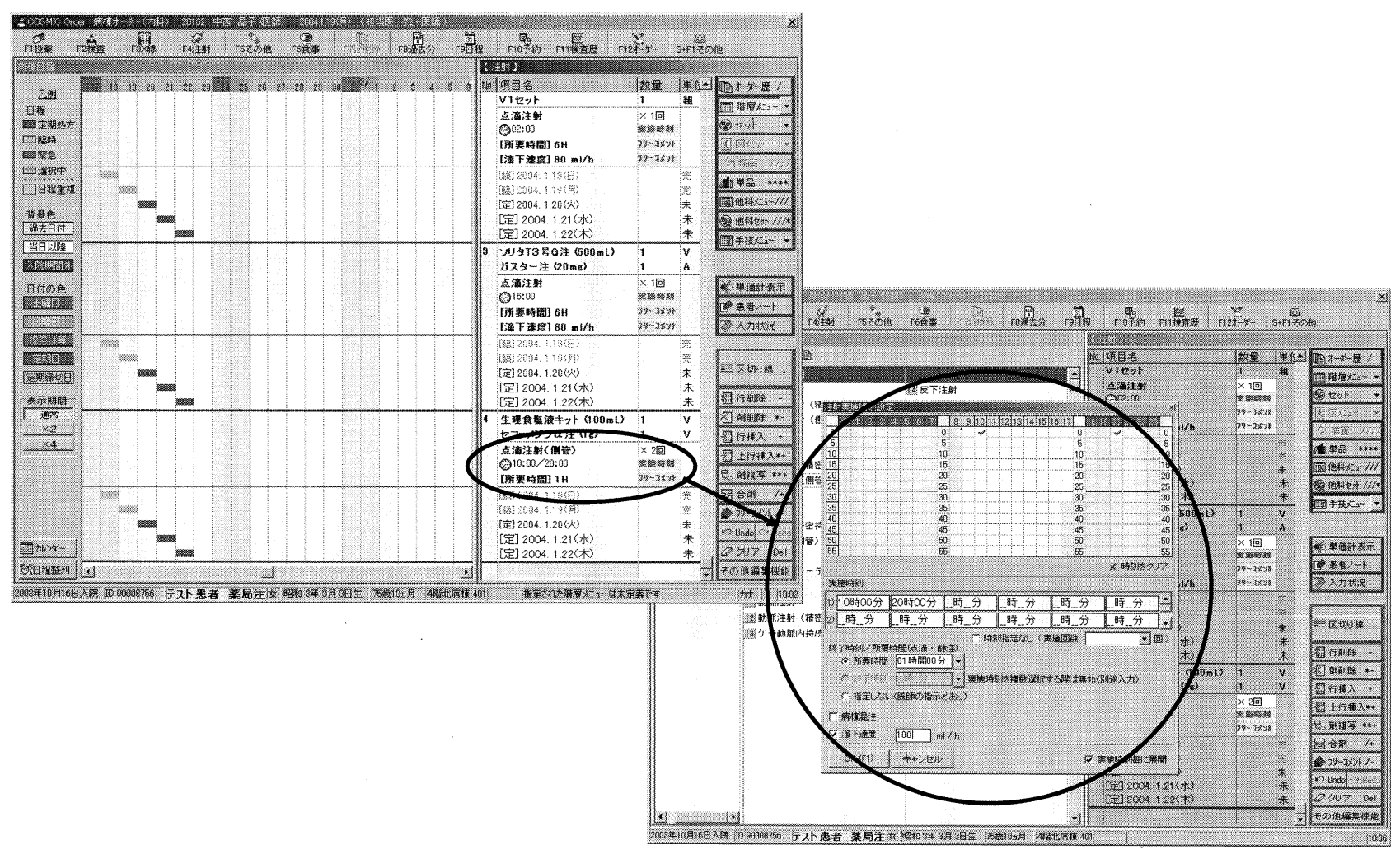

Fig. 1. 当院使用の注射オーダエントリシステムの入力画面 

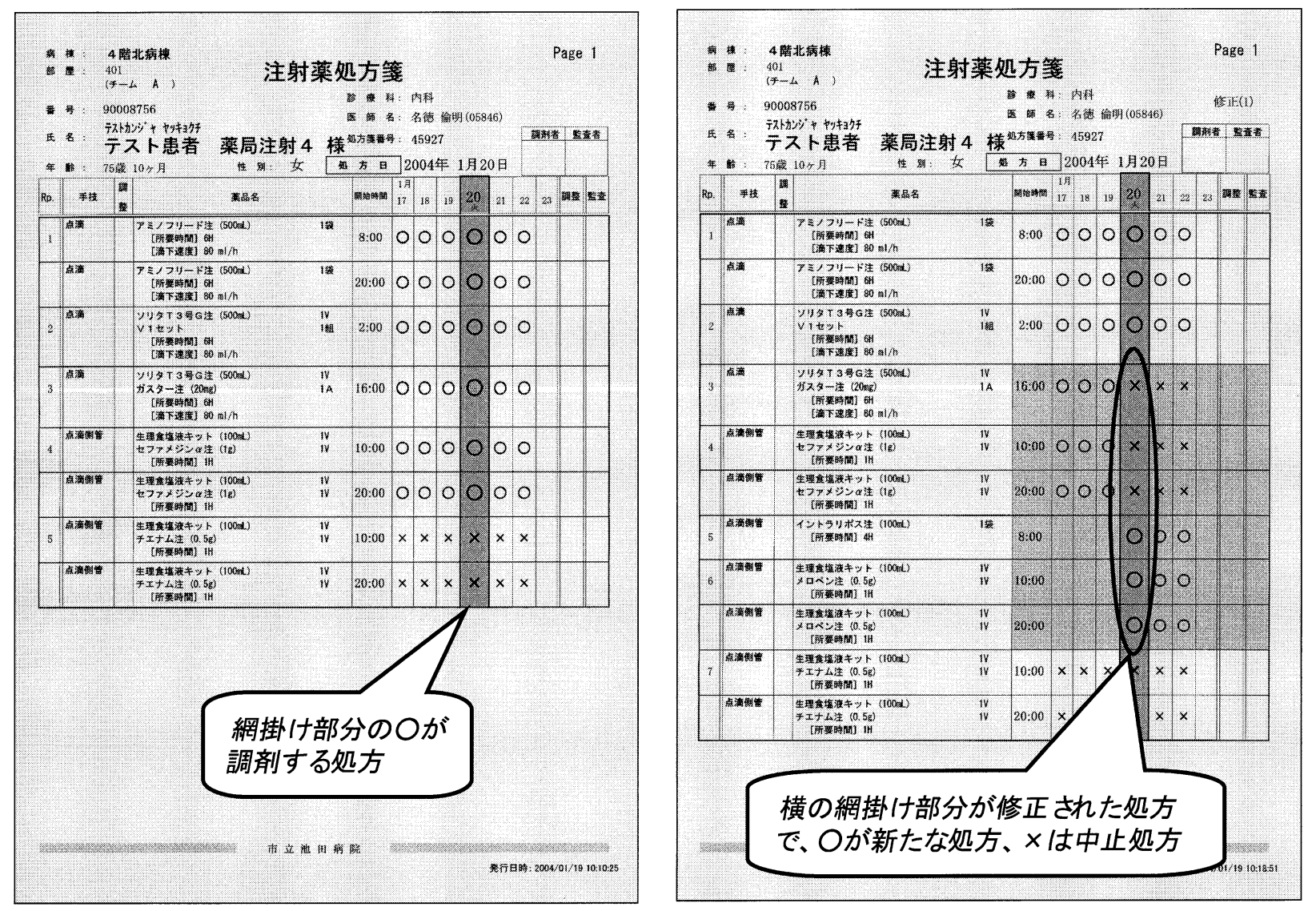

Fig. 2. 当院使用の注射薬処方せんと修正された注射薬処方せん

した。

2 ）混合調製後の返却本数および廃棄による損失金額 の比較

注射オーダエントリシステム導入前の 4 カ月間(平成 13 年 1 月 4 日〜 4 月 27 日) と導入後の 4 力月間(平成 16 年 1 月 4 日〜 4 月30日)で，薬郕部で混合調製した点滴用 注射薬で返却されたもののうち，再使用可能であるもの は転用，再使用不可能であるものは廃棄とし，両者を集 計した。また，平成16年 3 月18日〜 4 月30日までの廃棄 分より，廃棄 1 本あたりの薬価換算金額を計算し，導入 前後の廃棄金額を算出比較した。

3 ) 調剂ミスおよび過誤件数の比較

注射オーダエントリシステム導入前の 4 力月間(平成 12 年 10 月 1 日 平成 13 年 1 月 31 日) と導入後の 4 力月間 (平成16年 1 月 4 日〜 4 月30日) に発生した当院での注射 薬調剂システムで分担している各業務 ${ }^{2}$ ，すなわち，受 付, ラベル作成, 計数調剤, セット化拉よび混合調製で の調剂ミスおよび過誤件数を，調剤ミスおよび過誤発見 箇所別および発生箇所別に調査した.

\section{結果}

\section{1. 注射薬の処方本数および混合調製本数の比較}

Fig. 3 に，注射オーダエントリシステム導入前後での 注射薬処方せんで前日17時までに受け付けた 1 日あたり の点滴用注射薬本数と薬剤部で混合調製した点滴用注射 薬本数(返却分を除く)を示した。前日17時までに受け付 けた本数は，導入前が189本であり，導入後が260本と導 入後の方が約1.4倍に増加した。また，混合調製した本 数も同様に導入前134本，導入後189本と約1.4倍に増加 した。

Fig. 4 に，注射オーダエントリシステム導入前後での 混合調製率(混合調製した点滴用注射薬本数/前日17時ま でに受け付けた点滴用注射薬本数)を示した。導入前は $70.9 \%$ ，導入後 $72.7 \%$ と約 $2 \%$ 増加した.

Fig. 5 に，注射オーダエントリシステム導入前後の投 与開始時間別混合調製率を示した。10時から12時30分ま での点滴用注射薬の混合調製率はシステム導入前・後と もに $52.6 \% ， 51.9 \%$ と約半数を占めた．15時から 17 時30 分の時間带ではシステム導入前 $25.8 \%$ であったのが，導 入後 $12.5 \%$ と半減したのに対し，17時30分から 22 時まで の時間帯ではシステム導入前 $15.4 \%$ あったのが，導入 
後は $30.7 \%$ と倍増し，顕著に高い混合調製率を示した。

\section{2. 混合調製後の返却本数および廃棄による損失金額の 比較}

Fig. 6 に注射オーダエントリシステム導入前後の薬剤 部で混合調製した点滴用注射薬の返却率を示した。返却 率は，システム導入前が $5.35 \%$ ，導入後が $4.22 \%$ と約 $1 \%$ 減少した。また, 転用・廃率率ともに減少した。

調査期間内の廃棄件数は102件で，薬価換算金額の合 計は161,595円，1本あたり1,584円であった。

\section{3. 調剤ミスおよび過誤件数の比較}

Table 1 に注射オーダエントリシステム導入前後の薬

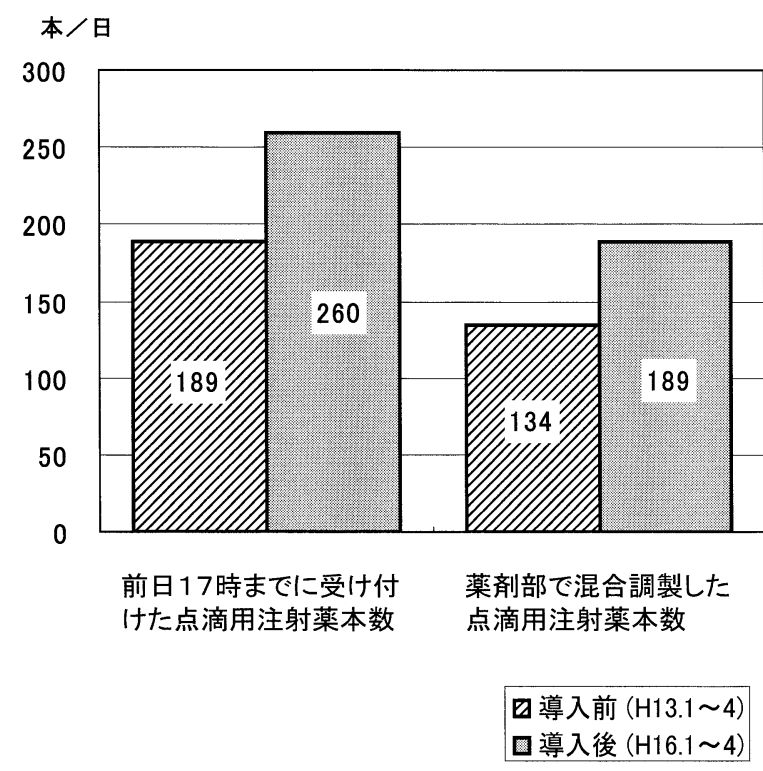

Fig. 3. 注射オーダエントリシステム導入前後での注 射薬処方せんで前日17時までに受け付けた 1 日あたりの点滴用注射薬本数と薬荗部で混合 調製した点滴用注射薬本数(返却分は除く)
剂部での調剂ミスおよび過誤発見箇所別件数および比率 を，Table 2 に調剤ミスおよび過誤発生箇所別件数およ び比率を示した。調剤ミスおよび過䛊率は, システム導 入前 $2.23 \%$ に比べ，導入後 $0.26 \%$ と大幅に減少した。発 見箇所別では, システム導入前では各業務(受付, ラベ ル作成, 計数調剤, セット化業務)鑑査で発見された調 剂ミス $1.90 \%$ ，最終鑑査(混合調製業務の鑑査を含む)で 発見された調剤ミス $0.28 \%$, 病棟に払い出した後発見さ れた調剤ミスが $0.04 \%$ でったが，導入後は各業務鑑査 で発見された調剂ミス $0.16 \%$, 最終鑑査で発見された調 剤ミス $0.1 \%$ あ゙り，薬剤部内ですべて調剤ミスを防ぐ ことが可能となった。 また, Table 2 に示すように, 発 生箇所別では, システム導入前のラベル作成業務での調 剤ミスが半数を占めていたのに対して, 導入後ではラベ ル作成業務での調剤ミスの発生は皆無であった。また， 計数調剂業務での調剂ミスが45件に対して，システム導 入後は23件と半減した。

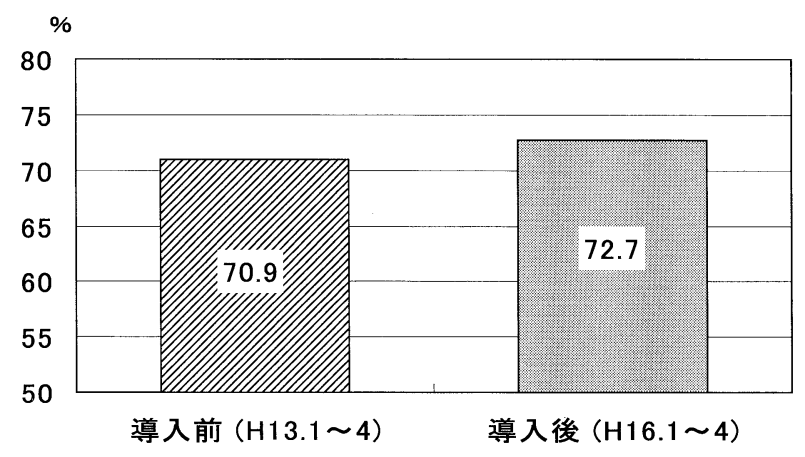

Fig. 4. 注射オーダエントリシステム導入前後での 混合調製率 (混合調製した点滴用注射薬本数 (返却分は除く)/前日17時までに受け付けた 点滴用注射薬本数)

導入前 $(H 13.1 \sim 4)$

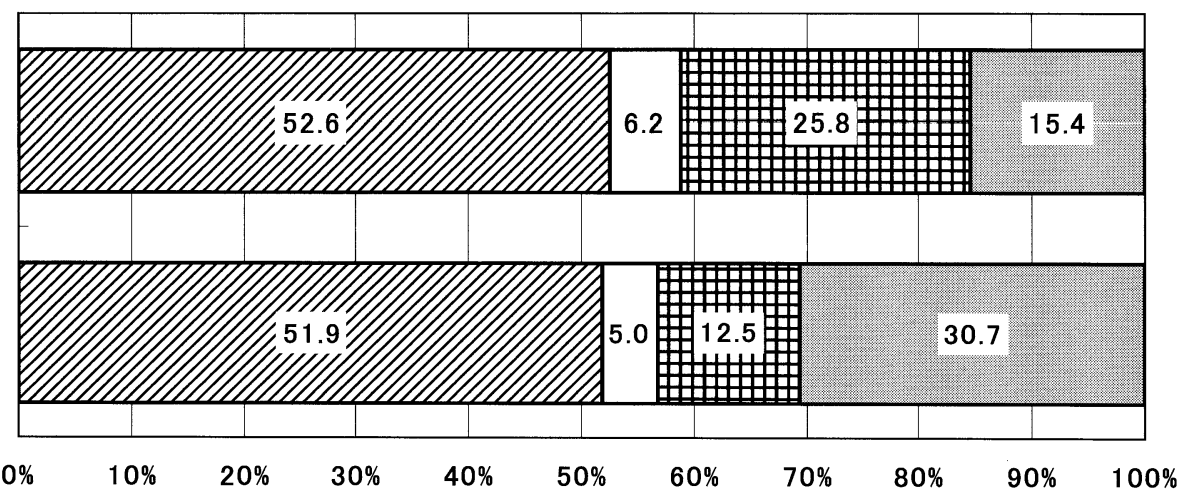

導入後 $(H 16.1 \sim 4)$

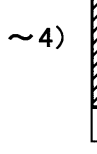

口12:30 15:00

田 15:00 17:30

$\square 17: 30 \sim 22: 00$

Fig. 5. 注射オーダエントリシステム導入前後での投与開始時間別混合調製率 


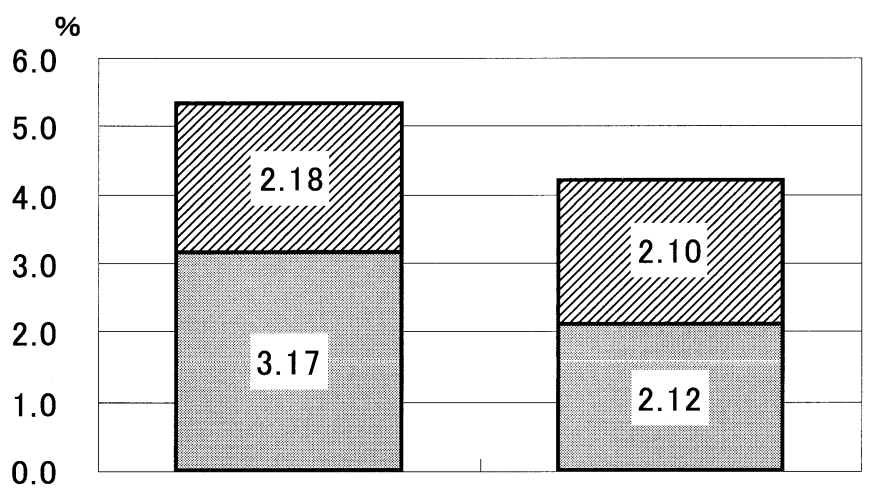

導入前 $(H 13.1 \sim 4)$
導入後 $(H 16.1 \sim 4)$

口転用

口廃棄

Fig. 6. 注射オーダエントリシステム導入前後の 薬剤部にて混合調製した点滴用注射薬の 返却率

\section{考察}

薬剂師が適正な注射薬調剤を行うには，日本病院薬剂 師会の提唱する ${ }^{5)}$ 「注射剂調剂」に必要な処方せん記載 項目を満たす必要がある。しかし，注射オーダエントリ システムが導入されていても，それらの項目の入力方法 が困難であったり手間のかかるシステムであれば，医師 が入力時に，これらの項目を自ら簡略化することも予測 される，特に，当院では，投与開始時間の入力が，注射 薬の混合調製をする上で非常に重要である，また，薬剤 師が処方を鑑査する上で，薬物療法全体の指示の流れが わからなくては確実な鑑査は行えない。従来報告されて いる注射オーダエントリシステムは，処方せんとして は，当日 1 日分単位の処方のみの印字であり，1施行分 を 1 処方として処方せんに印字されない6,7). 当院では, これらの点を解決し，混合調製を含めた注射薬調剤に適 したシステムを構築した。

薬剤部で混合調製を行う点滴用注射薬は，投与前日 17

Table 1. 注射オーダエントリシステム導入前後の薬剤部での調剤

ミスおよび過誤発見箇所別件数掞よび比率

\begin{tabular}{|c|c|c|c|c|c|c|c|c|}
\hline & $\begin{array}{l}\text { 混合調製 } \\
\text { 本数 (本) }\end{array}$ & & $\begin{array}{c}\text { 各業務*1 } \\
\text { 監査 } \\
\end{array}$ & 最終監査*2 & 病棟交付 & 患者施行 & 合 & 計 \\
\hline \multirow{2}{*}{$\begin{array}{c}\text { 導入前 } \\
(H 13.1 \sim 4)\end{array}$} & \multirow{2}{*}{9,611} & 過誤件数 (件) & 183 & 27 & 4 & 0 & & 214 \\
\hline & & 過誤率 (\%)*3 & 1.90 & 0.28 & 0.04 & 0.00 & & 2.23 \\
\hline \multirow{2}{*}{$\begin{array}{c}\text { 導入後 } \\
(\mathrm{H} 16.1 \sim 4)\end{array}$} & \multirow{2}{*}{15,484} & 過誤件数（件） & 24 & 16 & 0 & 0 & & 40 \\
\hline & & 過誤率 (\%)*3 & 0.16 & 0.10 & 0.00 & 0.00 & & 0.26 \\
\hline
\end{tabular}

* 1 各業務監査とは、受付、ラベル作成、計数調剂、セット化業務監査とする

$* 2$ 混合調製業務の監査を含む

*3 過誤率は、調剂過誤件数 /薬剂部混合調製本数

Table 2. 注射オーダエントリシステム導入前後の薬剤部での調剤 ミスおよび過誤発生䇢所別件数㧍よび比率

\begin{tabular}{|c|c|c|c|c|c|c|c|c|}
\hline & $\begin{array}{l}\text { 混合調製 } \\
\text { 本数 (本) }\end{array}$ & & 受 付 & $\begin{array}{l}\text { ラベル } \\
\text { 作成 }\end{array}$ & 計数調剂 & セット化 & 混合調製 & 合 計 \\
\hline \multirow{2}{*}{$\begin{array}{c}\text { 導入前 } \\
(\mathrm{H} 13.1 \sim 4)\end{array}$} & \multirow{2}{*}{9,611} & 過誤件数 (件) & 33 & 109 & 45 & 20 & 7 & 214 \\
\hline & & 過誤率 (\%)*1 & 0.34 & 1.13 & 0.47 & 0.21 & 0.07 & 2.23 \\
\hline \multirow{2}{*}{$\begin{array}{c}\text { 導入後 } \\
(\mathrm{H} 16.1 \sim 4)\end{array}$} & \multirow{2}{*}{15,484} & 過誤件数 (件) & 0 & 0 & 23 & 3 & 14 & 40 \\
\hline & & 過誤率 (\%)*1 & 0.00 & 0.00 & 0.15 & 0.02 & 0.09 & 0.26 \\
\hline
\end{tabular}

* 1 過誤率は、調剂過誤件数/薬剂部混合調製本数 
時までに受け付けた処方せんに記載され，投与開始時間 が10時から22時までのものを対象としている．注射オー ダエントリシステム導入前に比べ，導入後の投与前日 17 時までに受け付けた点滴用注射薬の本数が増加している のは, 従来は, 注射薬処方せんの指示記載欄が最大 7 日 分であり，その注射薬処方せん更新時での医師の処方指 示忘れをオーダエントリシステム導入により防止できた ものと考えられる．当院の注射オーダエントリシステム は，原則，投与開始時間および投与速度等を入力しなけ れば，オーダ不能なシステムとした。このようなシステ ムにより，前日17時までに受け付けた点滴用注射薬の中 で混合調製の対象となる処方の比率が，わずかではある がシステム導入後に増加したのは，手術や処置等の時間 が不確定なために投与開始時間が未定の場合を除き，ほ とんどの処方で投与開始時間が指示されたことで，混合 調製率に反映されたものと考える。

また，注射薬の投与間隔も，注射薬処方せんを鑑査す る上で重要な項目のひとつである. システム導入前の注 射薬処方せんでは，投与開始時間記載欄に従来の看護勤 務体制に併せた既定時間 (10時，16時)が印刷されてお り，したがって，投与開始時間もこの既定時間の中から 選択する場合が多くみられた。これらに対し，薬剤部で は特に投与間隔を厳密に取らなければならない薬剤につ いて, 疑義照会や医師への啓蒙を行ってきた. システム 導入後は，既定時間の中から投与開始時間を選択するの ではなく，投与開始時間を自由に選択できるため，さら には薬剤部による疑義照会や啓蒙により，指示時間帯が 15時から17時30分より，17時30分から22時までの点滴実 施開始分に大きく変動があったものと考えられる.

注射薬の指示は, 内用・外用薬に比べ, 病態の急変や 注射薬そのものの特性の違い ${ }^{8}$ により, 処方内容の変更 および中止が多くみられる。従来, 指示の伝達の不備に より返却される点滴用注射薬が多くみられたが，注射 オーダエントリシステム導入により, 処方の伝達が円滑 に行われるようになり，わずかではあるが返却率が減少 した.また，返却率減少による経済効果は，薬剤部での 年間混合調製本数を, 本年 4 カ月の調査本数より推定し て 71,905 本/年とし，システム導入前後での廃棄率の差 $1.05 \%$ ，廃棄混合調製注射薬 1 本あたり 1,584 円で換算 すると，年間 $1,195,924$ 円の廃棄による損失を防いだこ とになる。さらに, この廃棄分の調製に使用したシリン ジ,針等の医療材料費も加えると無視できない金額とな る。

調剤ミスおよび過誤件数は，システム導入前 $2.23 \% に$ 比べ $0.26 \%$ と大幅に減少した. またラベル作成業務につ いては，オーダエントリシステムと注射薬配薬鑑査シス テム泉を連動させたため, 調剤ミスおよび過誤がなく なった。一方, 混合調製業務での調剂ミスおよび過誤件
数はシステム導入前に比べ，導入後はむしろ増加した。 この増加は, 調査期間中に人員配置替えが行われ，それ による経験不足が，単純な調剤ミスを招いたと考えられ たが，システム導入前に経験したような薬剤の取り違え 等の危険度の高い調剤ミスおよび過誤は導入後にはみら れなかった。 また，システム導入後には病棟に払い出さ れた後に発見された調剤ミスおよび過誤もなくなり，薬 剂部での注射薬調剂業務のシステムが確立されてきたも のと考える.人的要因による過誤を皆無にすることは不 可能であると考えるが，オーダエントリシステムを導入 することは，ハインリッヒの法則 ${ }^{10)}$ 踏まえ，些細な調 剤ミスを減少させることにより, 結果的に大きな調剂過 誤，すなわち病棟に払い出される点滴用注射薬の調剂過 誤を未然に防止することが可能となった。

このように，当院での混合調製を含めた注射薬調剤に 適した独自のオーダエントリシステムを構築し, 導入す ることにより，医師による処方指示忘れや処方変更，中 止等が減少し, 混合調製本数抢よび率が増加し, 薬剂部 にて混合調製を行った点滴用注射薬の返却率が減少し た。また，処方せんの不備や不明瞭な記載が減少したの みならず，投与開始時間や投与速度等の注射薬処方也ん を鑑査する上での非常に重要な項目の指示が行われるよ うになった。調剤ミスおよび過誤に関しては，計数調剂 およびラベル印字等の調剤ミスが減少し，それにより病 棟に払い出された後発見される調剂ミスおよび過誤をな くすことが可能となった。

これらの結果は, 今回構築した注射オーダエントリシ ステムが，適正な注射薬調剤を行う上で非常に有用であ ることを示し，混合調製を含む注射薬調剤に適した注射 オーダエントリシステムであると考える。

\section{引用文献}

1) 名徳倫明，五十嵐恵美子，冨田由美，村山洋子，中 西晶子, 下村一徳, 深尾知子, 乾とし子, 藤原紀子, 阪本絵美，川口進一，土師久幸，「処方鑑査におけ る注意点一覧」を利用した注射薬処方鑑査の現状と その評洒, 医療薬学, 30, 594-600 (2004).

2) 川口進一，名徳倫明，下村一徳，乾とし子，陶山忠 士，土師久幸，チーム医療における薬剂師の役割一 病棟薬局での一般輸液の混合一, 医療薬学, 27, 565570 (2001).

3) 石本敬三, 高濱清子, 注射剂調剂時の処方鑑査, 月 刊薬事, 34, 2711-2725 (1992).

4) 塙久美子, 平山武司，小川幸雄，黒山政一，矢後和 夫，注射剤処方オーダ疑義照会の現状，日本病院薬 剂師会雑誌，32，1101-1105 (1996).

5) 日本病院薬剂師会薬剂業務委員会，入院患者のため の注射剂調剂指針, 日本病院薬剤師会雑誌, 37, 287291 (2001). 
6) 寒河江喜紀, 福井了三, 吉岡克己, 近藤克幸, 松本 喜良，鈴木敏夫，当院に扔ける注射オーダーシステ ムの構築とその評価, 医療薬学, 27, 159-166 (2001).

7) 前田剛司, 坂田洋, 注射薬自動払出し装置の構築と 評価, 医療薬学, 28, 495-501 (2002).

8) 室井延之, 細井さち子, 小川雅史, 林昌洋, 注射薬 の服薬指導と副作用回避への取り組み, 月刊薬事, 43, 247-252 (2001).
9) 名徳倫明，富田由美，村山洋子，五十嵐恵美子，中 西晶子, 媣尾知子, 藤原紀子, 下村一德, 川口進一, 土師久幸, 注射薬配薬監査システムの構築と導入効 果, 医療薬学, 29, 421-426 (2003).

10）野間秀一，平松隆，山田芳敬，長谷川信策，松葉和 久，ヒューマンファクターからみた調剤に扔ける安 全管理への取組み, 月刊薬事, 41, 2283-2289 (1999). 